\title{
Balıkesir şehir merkezinde trafik kaynaklı hava kirliliği seviyelerinin analizi
}

\author{
Atilla MUTLU* \\ Balıkesir Üniversitesi Mühendislik Fakültesi, Çevre Mühendisliği Bölümü, Çă̆ış Kampüsü, Balıkesir \\ Geliş Tarihi (Recived Date): 26.07.2018 \\ Kabul Tarihi (Accepted Date): 20.09.2018
}

\section{Özet}

Bu çalışmada, ülkemizin nüfus ve ulaşım açısından en yoğun şehirleri olan İstanbul, İmir ve Bursa illerini birbirine bağlayan karayolu ă̆ları ortasında bulunan Balıkesir il merkezinde trafikten kaynaklanan hava kirliliği seviyeleri incelenmiştir. İl merkezinde bulunan toplam 24 kavşak analiz edilmiş ve bu kavşaklardan geçen taşıt sayımları yapılmıştır. Elde edilen veriler COPERT programı yardımı ile analiz edilerek, kirleticilere ait trafik kaynaklı emisyonlar hesaplanmıştır. İncelenen toplam 24 kavşakta oluşan trafik faaliyetleri neticesinde, sicak ve soğuk iklim özellikleri dikkate alınarak, yapılan analizler sonucunda yıllık olarak yaklaşık 682 ton $\mathrm{CO}$ ve 133 ton $N O_{x}$ emisyonlarının trafik kaynaklı olarak atmosfere salındığı tahmin edilmektedir. Il merkezinden geçen İmir-Bursa-Istanbul ana ulaşım hattı üzerinde bulunan kavşaklarda trafik yoğunluğunun diğer kavşaklardan daha fazla ve dolayıslyla atmosfere verilen $\mathrm{CO}$ ve $N O_{x}$ kirleticileri ile yakıt tüketimlerinin daha fazla olduğu tespit edilmiştir.

Anahtar kelimeler: Trafik, CO, NO, Balıkesir, COPERT.

\section{Analysis of traffic-related air pollution levels in downtown Balikesir}

\begin{abstract}
In this study, air pollution levels in related to traffic in downtown Ballkesir where is located in the center of highway networks connecting Izmir, Bursa and İstanbul, which are the most dense cities of our country in terms of population and transportation, has been examined. A total of 24 intersections in the downtown were analyzed and the vehicles were counted that crosses through these junctions. The data was analyzed in
\end{abstract}

\footnotetext{
*Atilla MUTLU, amutlu@balikesir.edu.tr, http://orcid.org/0000-0002-0777-0863
} 
the COPERT software, then, traffic-related emissions of pollutants were determined. As a result of the traffic activities in the 24 intersections, considering hot and cold climate characteristics, it was estimated that approximately 682 tons of $C O$ and 133 tons of NOx emissions per year were released to the atmosphere due to traffic-related activities. It $h$ as been determined that traffic density is higher at thoseinter sections on the main transportation line of Izmir-Bursa-Istanbul that passes through the downtown and, therefore, the released CO and NOx emissions to the atmosphere, and the amount of fuel consumption have been detected to be higher than the other intersections.

Keywords:Traffic, $\mathrm{CO}, \mathrm{NO}_{x}$, Balikesir, COPERT.

\section{Giriş}

Günümüzde, şehir merkezlerinde ulaşım faaliyetlerinden kaynaklanan hava kirliliği önemli oranda artmakta ve hem lokal ve hem de global anlamda ciddi bir sorun haline gelmektedir [1]. Bunun sonucunda hava kalitesinde düşüş gerçekleşmekte, insan ve diğer canlıların sağlığı üzerinde olumsuz etkiler yaratmaktadır [2-4]. Şehir merkezi hava kalitesini, şehir içi trafiğinin önemli bir parçası olan motorlu taşıt egzozlarından dış ortama verilen zararlı gazlar olumsuz yönde etkilemektedir. Pan ve ark. [5], yapmış oldukları çalışmada, Çin'in başkenti Pekin'de $\mathrm{PM}_{2.5}$ emisyonlarının yaklaşık 1/3'ü motorlu taşıtlardan salındığını belirtmişlerdir.

Şehir merkezlerindeki yoğun trafik faaliyetleri sadece hava kirliliği sorunu oluşturmadıkları gibi aynı zamanda gürültü kirliliği sorunlarını da beraberinde getirmektedirler [3]. Avrupa Çevre Ajansı'nın (EAE) 2015 yılı raporunda belirtildiği üzere, hava kirliliği sorunu günümüzde Avrupa'da en önemli çevresel sorunların başında gelmekte olup 430,000'den fazla erken doğum vakası nedeniyle prematüre bebek ölümlerine neden olduğu, ayrıca en az 10,000 kadar benzer vakalarla prematüre bebek ölümlerinin de çevresel gürültü nedeniyle meydana geldiği rapor edilmiştir [6].

Ulaşım faaliyetlerinin en önemli kısmını oluşturan motorlu taşıtlardan dış ortama salınan egzoz gazlar içerisinde bulunan belli başlı bileşikler; karbon monoksit (CO), azot oksitler $\left(\mathrm{NO}_{\mathrm{x}}\right)$, partikül maddeler (özellikle $\left.\mathrm{PM}_{10}\right)$, kükürt dioksit $\left(\mathrm{SO}_{2}\right)$, aldehitler, ketonlar, karboksilik asitler gibi kısmen yanmış hidrokarbonlar (HC) ve parafinler, olefinler ve aromatikler gibi yanmamış hidrokarbonlar ile belirli oranlarda kurşun bileşikleri bulunmaktadır [7].

Ulaşım faaliyetlerinden diş ortama salınan gazlar, başlıca hava kirleticilerinin, karbonmonoksit (CO), karbondioksit $\left(\mathrm{CO}_{2}\right)$, uçucu organik bileşikler (VOCs), hidrokarbonlar $(\mathrm{HCs})$, nitrojen oksitler $\left(\mathrm{NO}_{\mathrm{x}}\right)$ ve partikül madde $(\mathrm{PM})$ seviyelerinin artmasına [8,9] ve sera gazı emisyonlarının \%25 oranında artmasına neden olduğu ifade edilmektedir. Avrupa Çevre Ajansı'nın (EEA) en son raporuna göre, ortaya çıkan çevresel sorunların birçoğu yeni AB hedeflerine ulaşmak için gerekli çabaların ciddi anlamda arttırılması gerektiği yönündedir [10].

Avrupa Birliği ve Amerika Birleşik Devletleri’nde yapılan farklı çalışmalar sonucunda, trafik yoğunluğunun yaşandığı işlek yolların yakınında yaşayan insanların aşırı hava kirliliği seviyelerine maruz kaldığı belirtilmektedir $[9,10] .2010$ yılında, yol kenarındaki hava kalitesi izleme istasyonlarının \% 44'ünde yasal sınırların üzerinde 
trafik kaynaklı nitrojen dioksit $\left(\mathrm{NO}_{2}\right)$ seviyeleri kaydedilmiştir [10]. Ayrıca, bu alanların \% 33'ünde partikül madde $\left(\mathrm{PM}_{10}\right)$ seviyeleri yasal limiti aşmıştır. Bu kirleticiler kardiyovasküler sistemi, akciğer fonksiyon bozukluklarına bağlı olarak solunum sistemlerini ve karaciğer fonksiyon bozukluklarına bağlı olarak da dolaşım sistemini etkiledikleri ifade edilmiştir [2,10].

Ulaştırma faaliyetlerinden kaynaklanan partikül madde salınımları lokal hava kalitesi üzerinde önemli rol oynamaktadır. Karayolu ulaşım faaliyetlerinin, Avrupa şehirlerindeki PM salınımlarının yaklaşık \% 30'u ve OECD (Organisation for Economic Co-operationand Development) ülkelerinde, çoğunlukla dizel trafiğinden dolayı, \% 50'ye kadar PM emisyonlarından sorumlu olduğu tahmin edilmektedir [2]. Ancak, PM emisyonlarının çevresel hava kirliliği seviyelerine olan katkısı, toplam kirlilik seviyesinin \% 12 ile \% 70 oranlarında değişim göstermektedir. Düşük ve orta gelirli ülkeler (özellikle Asya, Afrika ve Orta Doğu ülkeleri) ulaşım kaynaklı kirlilikten orantısız olarak zarar görmektedir. Bu durumun nedeni, söz konusu ülkelerde halen aktif olarak eski ve verimsiz dizel araçların kullanımı ve düzenli olarak çalışan aktif toplu ulaşım ağlarının eksikliğinden kaynaklanmaktadır.

Kanada' da yapılan bir başka çalışmada ise, 2003-2016 yılları arasında yapılan ölçümler sonucunda, yıllık ortalama $\mathrm{NO}_{\mathrm{x}}, \mathrm{NO}_{2}$ ve $\mathrm{NO}$ konsantrasyonlarının önemli ölçüde azaldığı, bu azalışa karşı trafik kaynaklı diğer bir kirletici olan $\mathrm{PM}_{2.5}$ konsantrasyonlarında önemli bir değişim olmadığı gözlenmiştir. Azotlu bileşiklerdeki bu önemli azalmanın hem araçlardan ve hem de sanayi faaliyetlerinden kaynaklı salınımlardaki azalmaların neticesinde olduğu tahmin edilmektedir [11]. Yine aynı çalışmada, Kanada'da bulunan Ontario halkının \%25'i anayola $100 \mathrm{~m}$ mesafede veya otobanlara $500 \mathrm{~m}$ mesafede yaşadıkları ve bu düzenden dolayı trafik kaynaklı hava kalitesinin düşük seviyelerde olmasından dolayı ciddi anlamda sağlık sorunları riskleri ile karşı karşıya kaldıkları belirtilmiştir. Farklı bir başka çalışmada ise, ana yol güzergahlarına $300 \mathrm{~m}$ ile $500 \mathrm{~m}$ arasında değişen mesafelerde yaşayan insanların trafik kaynaklı hava kirliliğinden en çok etkilenen gruplar olduğunu belirtmiştir. Etkilenme şiddeti sadece mesafe ile sınırlı kalmayıp aynı zamanda, o bölgedeki meteorolojik koşullar, mevcut kirlilik seviyesi (arka plan seviyeleri) ve varsa diğer kirletici kaynaklardaki faaliyetlerin de etkili olduğu ayrıca belirtilmiştir [12].

Sağlığa zarar veren başka bir ulaşımla ilgili hava kirleticisi ise yer seviyesindeki ozon $\left(\mathrm{O}_{3}\right)$ olarak tanımlanır. Kent içi hava kirleticilerinden olan $\mathrm{O}_{3}$ astım gibi kronik solunum yolu hastalıklarında önemli rol oynamaktadır. Yer seviyesindeki ozonun ekosistem yapılarına ve işlevlerine zarar verdiği ve bunun da tarımsal üretkenliği etkilediği ve gıda güvenliğini tehdit ettiği bilinmektedir [2].

Bu çalışma kapsamında, ülkemizin nüfus ve ulaşım açısından en yoğun şehirleri olan İstanbul, İzmir ve Bursa illeri, arasındaki karayolu ağları ortasında bulunan Balıkesir il merkezinde karayolu trafiğinden kaynaklanan hava kirliliği seviyeleri incelenmiştir. Çalışmada, il merkezine ait seçilen kavşaklarda taşıt sayımı yapılmış ve sayımlara konu alan araç çeşitlerine göre emisyon faktörleri kullanılarak COPERT (COmputer Programme to Calculate Emissions from Road Transport) programı kullanılarak trafik kaynaklı kirletici emisyonları hesaplanmıştır. Çalışmada şehir merkezinde, motorlu taşıtlardan kaynaklanan temel kirleticilerin başında gelen karbon monoksit (CO) ve azot oksitler $\left(\mathrm{NO}_{\mathrm{X}}\right)$ kirleticilerine ait emisyon envanterleri oluşturulmuştur 


\section{Materyal ve Metod}

\section{1. Çalışma Yapılan Kavşaklar}

$\mathrm{Bu}$ çalışma, karayolu trafiğinden kaynaklanan hava kirliliği seviyelerinin araştırılması ve hava kirleticilerinin emisyon envanterlerinin belirlenmesi amacı ile Balıkesir il merkezinde yapılmıştır. Çalışma kapsamında, Balıkesir il merkezinde yoğun trafik akışlarının gözlemlendiği kavşaklarda araç sayımları yapılmıştır. Sayım yapılan kavşaklara ait konumlar Google Earth yardımıyla Şekil 1'de gösterilmiştir.

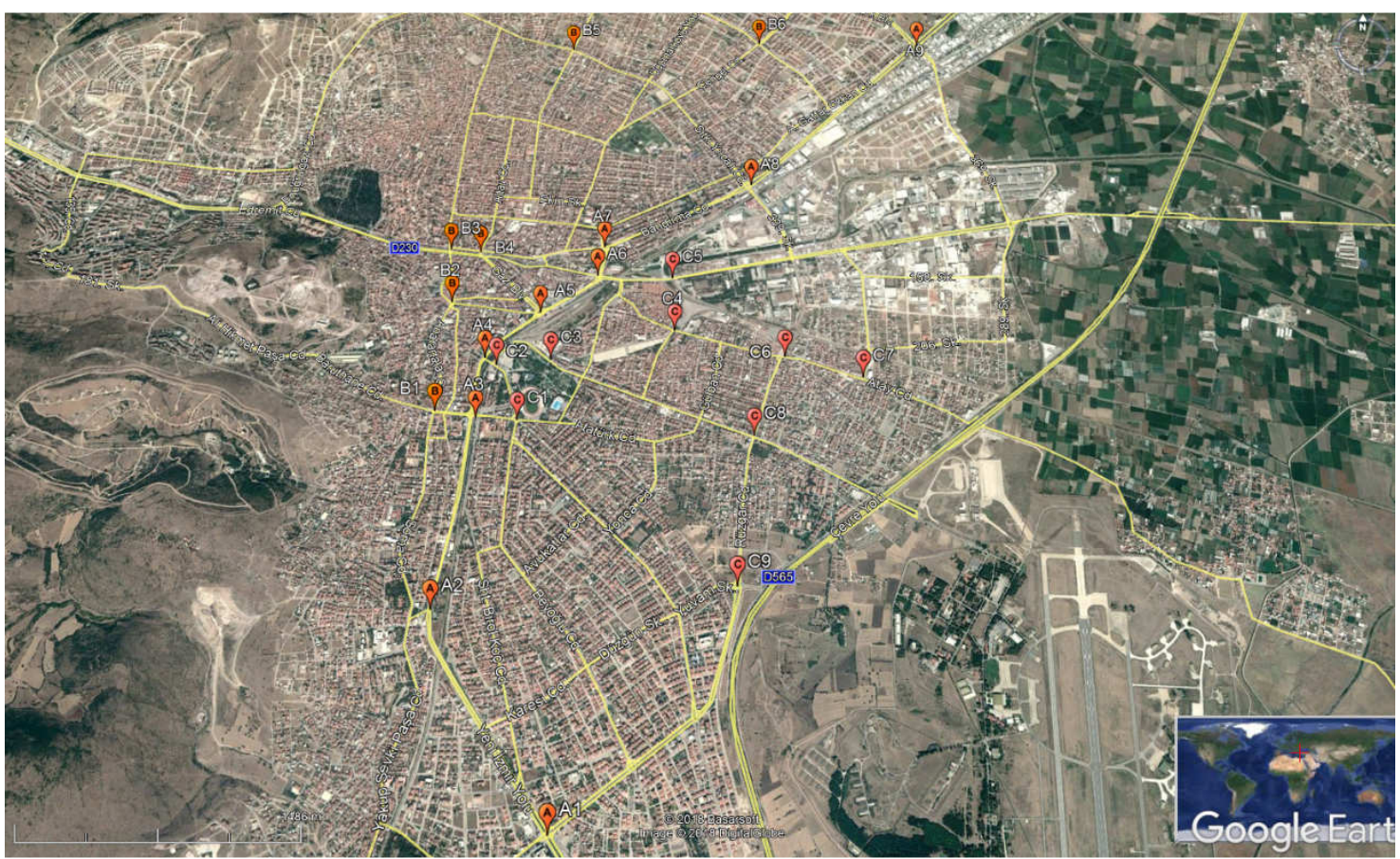

Şekil 1. Balıkesir il merkezinde araç sayımı yapılan kavşakların yerleri.

Sayım yapılan kavşaklar Şekil 1'de gösterildiği gibi şu şekilde kodlanmıştır: (A1) Adliye, (A2) Atatürk Devlet Hastanesi-ADH, (A3) Doğumevi, (A4) Vilayet, (A5) Gar, (A6) Altı Eylül, (A7) Otel Basri, (A8) Emniyet, (A9) Sanayi 2. Kap1, (B1) Çardaklı, (B2) Ali Hikmet Paşa, (B3) Deve Loncas1, (B4) Eski Camii, (B5) M.Akif Ersoy, (B6) Çengel Cad., (C1) Stadyum, (C2) Kapalı Spor Salonu, (C3) Vergi Dairesi, (C4) Ofis, (C5) Ağır Bakım, (C6) Atay Cad., (C7) Altıntaşlar, (C8) Rüzgar Cad., (C9) Savaştepe.

İl merkezi; nüfus, merkez ilçe konumları ve trafik yoğunluğu kriterlerine göre dört farklı bölgeleye ayrılmış olup, çalışmaya konu olan kavşaklar 3 grup halinde A, B ve C grupları olarak incelenmiştir. Şehir merkezinde konumlarına göre sınıflandırılmışlardır kavşaklar Şekil 2.'de sunulmuştur. 


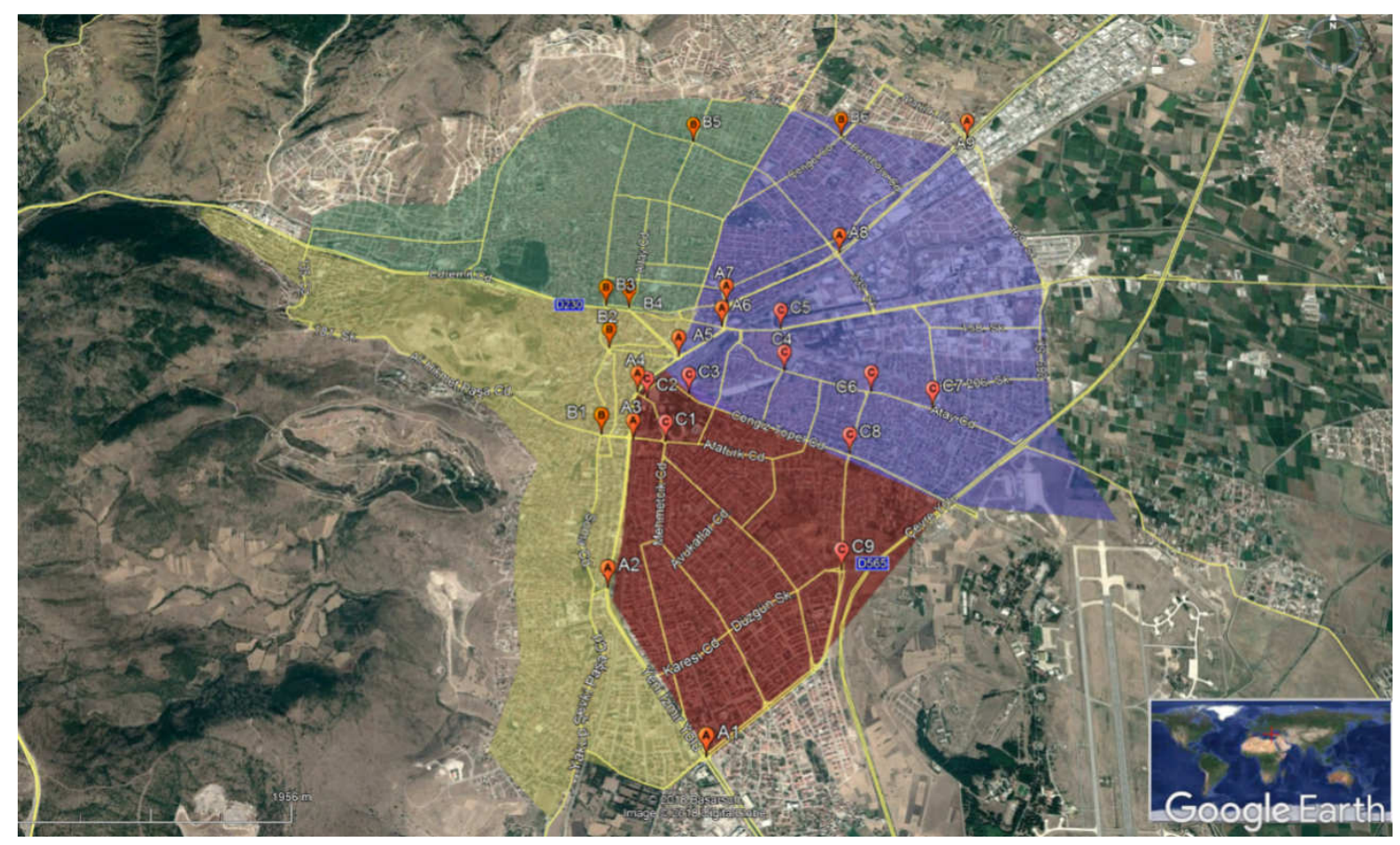

Şekil 2. Gruplara ayrılmış kavşakların yerleri.

Çalışma kapsamında mevcut durum analizleri (trafik ve nüfus yoğunlukları) yapılarak 4 bölgeye ayrılan Balıkesir il merkezinin bölgelere ayrılmış hali Şekil 2 üzerinde görülmektedir. 1. Bölge: şehir merkezinin güneydoğusu, bir başka ifadeyle, Yeni İzmir yolu ve Cengiz Topel Caddesi arasında kalan kısım kırmızı renk ile gösterilmiştir. 2. Bölge: şehrin kuzey batısını içeren bölge olmakla beraber Cengiz Topel Caddesi ile Oruç Pınar Köyü yolu arasında kalan alanlar ile sınırlandırılmıştır ve mavi renkle gösterilmiştir. 3. Bölge: Oruç Pınar Köyü Yolu ile Edremit Caddesi arasında kalan şehrin kuzeybatı kısmını oluşturan kısımdır ve yeşil renkle gösterilmiştir. Son bölge olan, 4. Bölge ise şehrin güneybatı kısmında kalan ve Edremit Caddesi ile Yeni İzmir yolu arasında kalan bölgedir ve turkuaz renginde gösterilmiştir. Ayrıca, üç farklı gruba ayrılmış olan kavşakların konumları da Şekil 2'de sunulan bölgelerde gösterilmiştir.

A grubuna dahil olan 9 adet kavşak bulunmaktadır. Bu kavşaklar; çevre yolu haricinde, Balıkesir il merkezinden geçen İzmir-Bursa-İstanbul hattı üzerinde bulunan ve Altı Eylül ile Karesi merkez ilçelerini ayıran ana arter üzerinde bulunan en yoğun trafik akışlarına sahip kavşakları temsil eder. Bu kavşaklar şehrin İzmir yönündeki girişi ile Bursa yönündeki çıkışı arasında bulunan Bandırma Yolu Caddesi, Vasıfçınar Caddesi ve İzmir Yolu Caddesi üzerinde bulunmaktadır (A1, A2, A3, A4, A5, A6, A7, A8 ve A9 kodlu kavşaklar). B grubuna dahil olan kavşaklar, Balıkesir şehir merkezinden geçen Bandırma Yolu Caddesi, Vasıfçınar Caddesi ve İzmir Yolu Caddesinin batısında kalan kavşakları temsil eden kavşaklardır (B1, B2, B3, B4, B5 ve B6 kodlu kavşaklar). C grubuna dahil olan kavşaklar ise $\mathrm{A}$ grubu ana kavşakların doğu kısmında kalan kavşakları temsil etmektedir (C1, C2, C3, C4, C5, C6, C7, C8 ve C9 kodlu kavşaklar).

\subsection{Kavşak Analizleri}

Çalışmaya konu olan kavşaklar Avrupa Çevre Ajansı tarafından kullanılan COPERT (COmputer Programme to Calculate Emissions from Road Transport) paket programı kullanarak analiz edilmiştir ve ilgili kavşaklara ait kirletici emisyonları hesaplanmıştır [13]. Kavşaklar ile ilgili simülasyon çalışmaları yapılırken bazı önemli parametrelerin 
model girdileri olarak belirlenmesi gerekmektedir. Bu parametreler; kavşakların coğrafi konumları, kavşaklara ait hat sayısı, akım yönleri ve numaraları, varsa sinyalizasyon sisteminin özellikleri, taşıt sayımlarına ilişkin ortalama istatistiksel değerler ve bu değerlere ait zaman ve saat dilimleri, gözlem yapılan saat dilimine ait kavşaktan geçen toplam araç sayısı (Toplam Akım), trafikte oluşabilecek araç kuyruğu uzunluğu (QLen ve QLenMax), simülasyon sonucu kavşaktan geçen tahmini araç sayısı (VEHS), kavşaktan geçen araçların neden olduğu CO emisyonu (gr) ve NOx emisyonu (gr), araçlara ait ortalama tahmin edilen yakıt tüketim miktarı, kavşakta sinyalizasyon sisteminden ve araç yoğunluğundan dolayı ortalama bekleme süresi ve kavşaklara ait yoğunluk indeksleri olarak tanımlanır.

COPERT modelinde genel olarak, ülke, trafik akışı ve yoğunluğu bilgileri (hız, araç dizini uzunluğu, şerit sayısı, araçlara ait ortalama odometre değerleri), soğuk veya sıcak koşullarına bağlı katsayılar ve ölçümlerin yapıldığı lokasyon (şehir, kırsal veya otoban) bilgileri kullanılarak o bölgedeki kirleticilere ait trafik kaynaklı emisyonlar hesaplanmaktadır. Kullanılan COPERT programına ait veri girdilerini gösteren ekran kesitleri Şekil 3'de sunulmuştur.

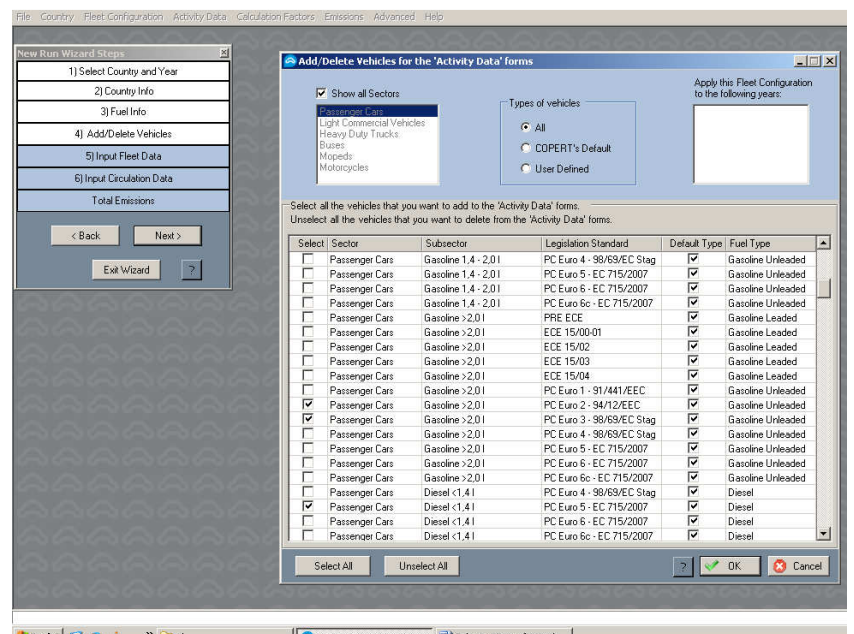

Şekil 3. COPERT'de araçlara ait farklı yakıt türlerinin işlenmesini gösteren ekran kesiti.

Şekil 3'de sunulan COPERT simülasyon programına ait ekran kesitinde, sayım yapılan araç türleri ve kullanılan yakıt türlerine ait faktörler Balıkesir ili için Euro3/4/5 olarak tespit edilmiştir. TÜİK verilerine göre, Balıkesir ilinde her bir aracin ortalama 12500 km yol katettiği ve yine ülke genelinde kullanılan farklı yakıt tiplerine göre (benzin, dizel veya LPG) araç istatistiklerine göre yakıt dağılımları da çalışma bölgesi için oluşturulmuştur [14].

Kavşaklara ait hat sayısı, akım yönleri ve numaraları öncelikle belirlenmiştir. Örnek olması bakımından, A-Grubuna ait toplam 9 adet kavşağa ait bilgiler Şekil 4'de sunulmuştur. 


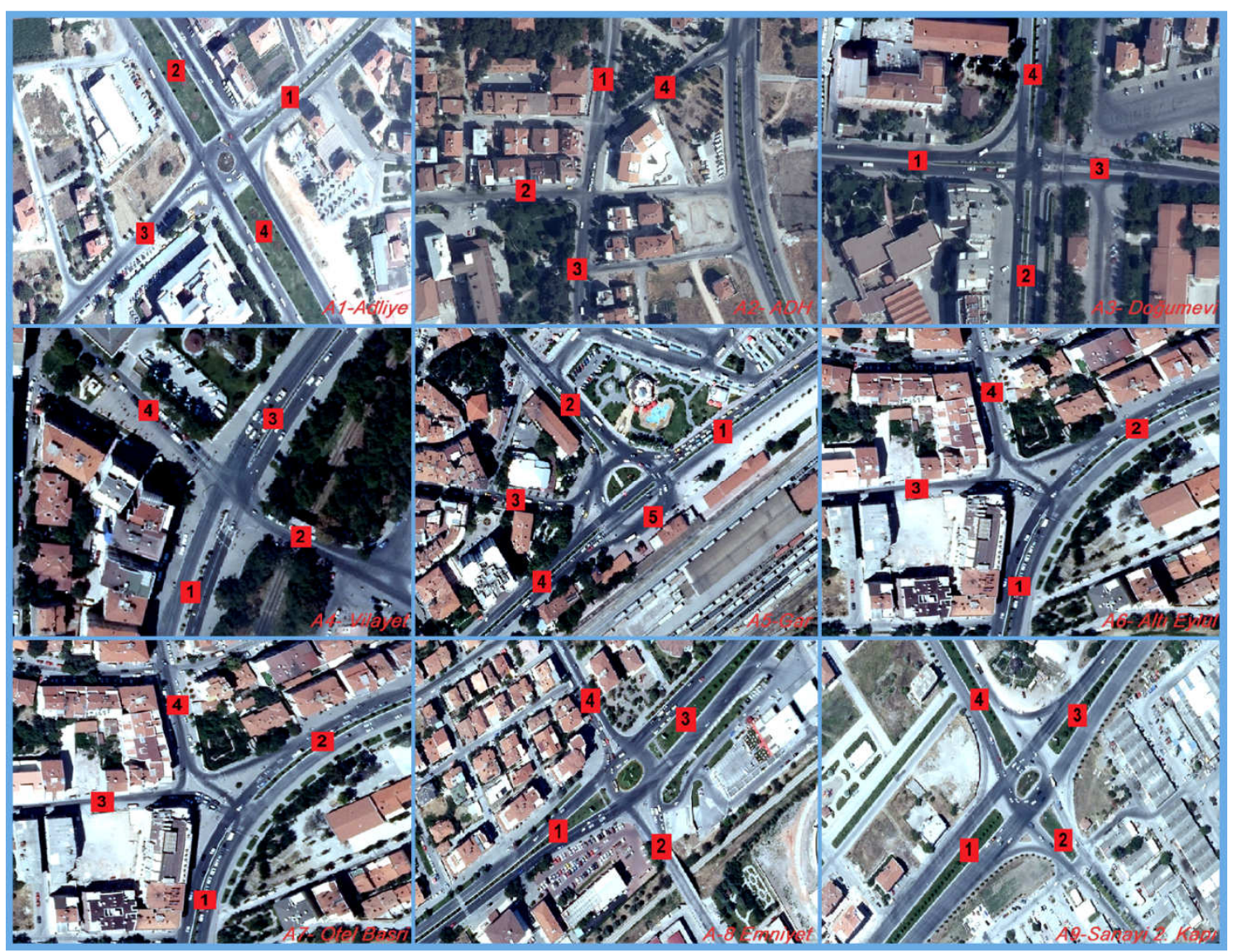

Şekil 4. Çalışmada analiz edilen A-Grubu kavşakların görselleri ve trafik akım yönleri.

İncelenen kavşaklara örnek olması bakımından, şehir merkezinde en yoğun kavşaklardan biri olan A5 kodlu Gar kavșağı; Vasıfçınar Caddesi ile Milli Kuvvetler Caddesi ve Gazi Bulvarının kesişmesinden oluşan 5 kollu sinyalize bir kavşaktır (Şekil 5).

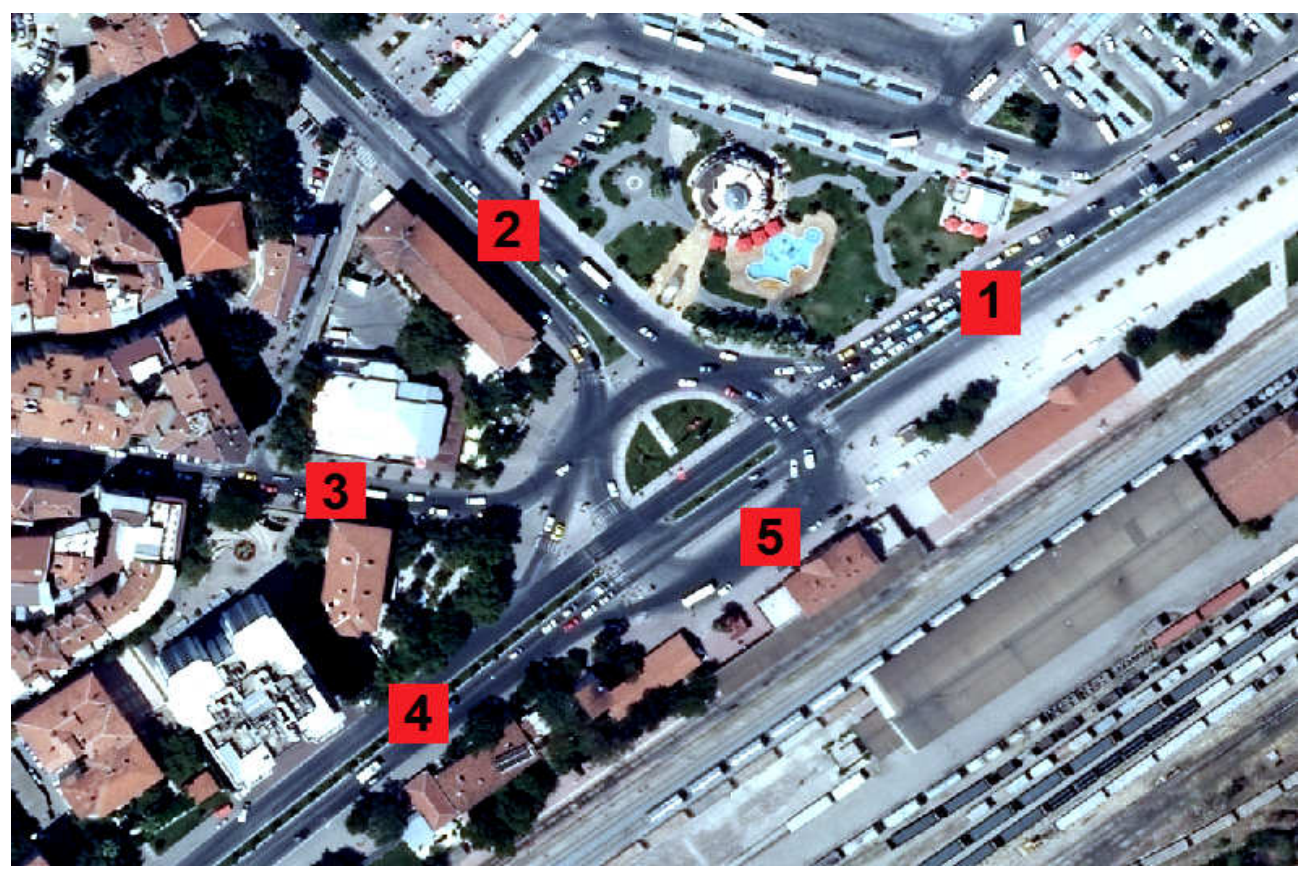

Şekil 5. Gar kavşağına ait görsel ve trafik akım yönleri. 
Kavşakta yeşil dalga sinyal sistemi uygulandığ için toplam devre süresi 114 sn olup, 3 fazlıdır. Ana akıma (1-4 hatları) 48 sn yeşil süre, diğer akımlara sırasıyla 30 sn ve 24 sn yeşil süre verilmiştir. Kavşaktaki trafik akımlarının yönü Şekil 5'de verilmiş olup kavşak ile ilgili detaylı sayım değerleri Tablo 1'de verilmiştir.

Sayımlar Valilik kapsamında, Çevre ve Şehircilik İl Müdürlüğü'nden alınan izinler çerçevesinde 2016 yılında Mart-Nisan ve Mayıs aylarında yapılmıştır. Trafik yoğunluğunun en fazla olabileceği haftanın ilk günü olan Pazartesi günü, sabah 7:009:00 saatleri arası, öğlen 12:00-14:00 ve akşam 16:00-18:00 saatleri arasında yapılmıştır. Ayrıca hafta içi ve hafta sonu yoğun olmayan 2 saatlik dilimlerde sayım yapılmıştır. Çalışma esnasında ölçüm yapılan kavşaklarda trafik akışını ve yoğunluğunu etkileyecek herhangi bir yol yapımı veya güzergah değişikliği rapor edilmemiştir. Belirtilen saat dilimleri arasında sayılan farklı tipteki araçlara ait ortalama geçiş değerleri Tablo 1'de sunulmuştur.

Tablo 1. Gar (A5) kavşağından geçen araç tipleri ve sayıları.

\begin{tabular}{lccccc}
\hline AKIŞ YÖNÜ & Otomobil & Kamyon & Otobüs & Kamyonet-Minibüs & Motosiklet \\
\hline 1- Gar Kavşağına & 824 & 6 & 81 & 84 & 40 \\
2- Gar Kavşağına & 267 & 41 & 44 & 76 & 16 \\
Gardan-1 yönüne & 491 & 42 & 69 & 145 & 22 \\
Gardan-2 yönüne & 248 & 5 & 41 & 71 & 9 \\
Gardan-3 yönüne & 685 & 10 & 37 & 250 & 64 \\
Gardan-4 yönüne & 643 & 6 & 99 & 156 & 33 \\
\hline Toplam & 3157 & 110 & 371 & 782 & 184
\end{tabular}

Sabah saatlerinde olmak üzere diğer kollardaki akımlar ile de karşılaştırmak suretiyle 1 nolu akım değerinin diğer akım değerlerine göre en yüksek çıktığı görülmüştür. Tablo 1'de sunulan sayım değerlerine göre A5 Gar Kavşağından en yoğun saatler olan sabah 8:00-9:00 saatleri arasında tüm hatlar dahil olmak üzere toplam 4604 aracın geçiş yaptığı tespit edilmiştir.

Çalışma kapsamında, diğer tüm kavşaklarda yapılan gerçek zamanlı taşıt sayımları ile ilgili trafik akış bilgileri analizlerinden elde edilen parametreler Tablo 2'de sunulmuştur.

Tablo 2. Çalışma kapsamındaki tüm kavşaklara ait taşıt sayıları.

\begin{tabular}{llcccc}
\hline No & \multicolumn{1}{c}{ Yer } & Grup & $\begin{array}{c}\text { Yoğunluk } \\
\text { Zamanı }\end{array}$ & $\begin{array}{c}\text { Yoğun } \\
\text { Saatler }\end{array}$ & $\begin{array}{c}\text { Toplam } \\
\text { Akım }\end{array}$ \\
\hline A1 & Adliye & A & Sabah & $7: 00-8: 00$ & 3244 \\
A2 & ADH & B & Sabah & $7: 30-8: 30$ & 2278 \\
A3 & Doğumevi & A & Sabah & $7: 45-8: 45$ & 2286 \\
A4 & Vilayet & A & Akşam & $17: 00-18: 00$ & 3401 \\
A5 & Gar & B & Sabah & $8: 00-9: 00$ & $\underline{\mathbf{4 6 0 4}}$ \\
\hline
\end{tabular}


Tablo 2. (Devam1).

\begin{tabular}{|c|c|c|c|c|c|}
\hline A6 & Altı Eylül & $\mathrm{A}$ & Sabah & $8: 30-9: 30$ & 3759 \\
\hline A7 & Otel Basri & $\mathrm{A}$ & Akşam & 18:00-19:00 & 3640 \\
\hline A8 & Emniyet & A & Akşam & $17: 45-18: 45$ & 3428 \\
\hline A9 & Sanayi 2. Kapı & A & Sabah & 8:00-9:00 & 2453 \\
\hline B1 & Çardaklı & B & Sabah & $7: 30-8: 30$ & 2341 \\
\hline B2 & $\begin{array}{l}\text { Ali Hikmet } \\
\text { Paşa }\end{array}$ & $\mathrm{B}$ & Öğle & 13:00-14:00 & 1929 \\
\hline B3 & Deve Loncası & B & Sabah & $8: 15-9: 15$ & 2383 \\
\hline B4 & Eski Camii & B & Akşam & 18:00-19:00 & 2023 \\
\hline B5 & M.Akif Ersoy & B & Sabah & $7: 30-8: 30$ & 1336 \\
\hline B6 & Çengel Cad. & $\mathrm{B}$ & Sabah & $7: 30-8: 30$ & 1538 \\
\hline C1 & Stadyum & $\mathrm{C}$ & Akşam & $17: 15-18: 15$ & 3171 \\
\hline C2 & $\begin{array}{l}\text { Kapalı Spor } \\
\text { Salonu }\end{array}$ & A & Akşam & $17: 15-18: 15$ & 1970 \\
\hline $\mathrm{C} 3$ & Vergi Dairesi & $\mathrm{C}$ & Akşam & $17: 45-18: 45$ & 1242 \\
\hline $\mathrm{C} 4$ & Ofis & $\mathrm{C}$ & Sabah & $7: 30-8: 30$ & $\underline{874}$ \\
\hline C5 & Ağır Bakım & $\mathrm{C}$ & Sabah & $7: 30-8: 30$ & 1798 \\
\hline C6 & Atay Cad & $\mathrm{C}$ & Sabah & $7: 30-8: 30$ & 1386 \\
\hline C7 & Altıntaşlar & $\mathrm{C}$ & Sabah & $7: 30-8: 30$ & 1456 \\
\hline C8 & RüzgarCad & $\mathrm{C}$ & Akşam & $16: 00-17: 00$ & 1420 \\
\hline C9 & Savaştepe & $\mathrm{C}$ & Akşam & $17: 00-18: 00$ & 1229 \\
\hline
\end{tabular}

Her bir grupta bulunan kavşaklarda öncelikle trafik akışının en yoğun olduğu zaman dilimleri sabah, öğle veya akşam saatleri belirlendi ve bu zaman dilimlerine ait taşıt sayımları en yoğun saat dilimlerinde yapılarak Tablo 2'de sunulmuştur. En yoğun kavşaklar, A grubunda bulunan kavşaklar olup A5 kodlu Gar kavşağında en yüksek araç geçişi tespiti yapılmıştır. Daha az yoğun kavşaklar B ve C gruplarındaki kavşaklar olup, en düşük araç geçişinin yapıldığı kavşak C4 kodlu Ofis kavşağı olduğu tespit edilmiştir.

\section{Sonuçlar}

$\mathrm{Bu}$ çalışma ile Balıkesir il merkezinde karayolu trafiğinden kaynaklanan hava kirleticilerinin emisyon envanterlerinin belirlenmesine çalışılmıştır. İl merkezinde yoğun trafik akışlarının gözlemlendiği kavşaklarda araç sayımları yapılmıştır. Sayımlara ait değerler COPERT modelinde işlenerek çalışma alanında trafik kaynaklı $\mathrm{CO}$ ve $\mathrm{NO}_{\mathrm{x}}$ emisyon hesaplamaları yapılmıştır. Çalışmada ölçülen ve girdi olarak kullanılan tüm parametreler; yer, grup, zaman, saatler ve toplam akım değerleri ve modelleme sonucuna bağlı olarak elde edilen tüm parametreler; trafikte oluşabilecek araç kuyruğu uzunluğu (QLen ve QLenMax), simülasyon sonucu kavşaktan geçen tahmini araç sayısı (VEHS), kavşaktan geçen araçların neden olduğu CO emisyonu (gr) ve NOx emisyonu (gr), araçlara ait ortalama tahmin edilen yakıt tüketim miktarı, kavşakta sinyalizasyon sisteminden ve araç yoğunluğundan dolayı ortalama bekleme süresi ve kavşaklara ait yoğunluk indeksleri gibi sonuçlar Tablo 3'de sunulmuştur. 
Çalışmanın bu bölümünde ayrıca, ölçüm yapılan kavşak gruplarına ait taşıt yoğunluğu, araç tipleri sayıları ve TÜİK verilerine bağlı farklı tipte yakıt kullanım oranlarına göre $\mathrm{CO}$ ve $\mathrm{NO}_{\mathrm{x}}$ emisyonları ve son olarak kavşak gruplarına ait yakıt tüketimleri istatiksel olarak kıyaslanmıș bu bölümde detaylı olarak açıklanmıștır. Ayrıca kavşaklarda oluşan araç kuyrukları ile yakıt tüketimleri arasında Korelasyon testleri yapılarak, her bir kavşakta oluşan araç kuyruklarının araç yakıt tüketimlerine etkisi araştırılmıştır.

Son bölümde ise, COPERT model geçerliliğini sağlamak amacı ile kavşaklarda gerçek zamanlı ölçülen araç sayıları (ölçülen) ile COPERT tarafından tahmin edilen araç sayıları (Model) arasındaki ilişki istatiksel olarak incelenmiş ve model geçerliliği açıklanmaya çalışılmıştır. 
Tablo 3. Tüm kavşaklara ait analiz sonuçları ve kirletici emisyonları.

\begin{tabular}{|c|c|c|c|c|c|c|c|c|c|c|c|c|c|}
\hline No & Yer & Grup & Zaman & Saatler & $\begin{array}{l}\text { Toplam } \\
\text { Akım } \\
\end{array}$ & Q Len & $\begin{array}{l}\text { QLen } \\
\text { Max } \\
\end{array}$ & VEHS & $\mathrm{CO}$ (gr) & $\begin{array}{l}\mathrm{NOx} \\
(\mathrm{gr})\end{array}$ & $\begin{array}{c}\text { Yakıt } \\
\text { Tüketimi } \\
\end{array}$ & $\begin{array}{c}\text { Sinyalize } \\
\text { Hizmet Süresi } \\
\end{array}$ & $\begin{array}{c}\text { Yoğunluk } \\
\text { Düzeyi }\end{array}$ \\
\hline A1 & Adliye & A & Sabah & 7:00-8:00 & 3244 & 60.5 & 509.5 & 3047.0 & 5353.3 & 1041.6 & 76.6 & 117.2 & F \\
\hline A2 & $\mathrm{ADH}$ & A & Sabah & 7:30-8:30 & 2278 & 174.7 & 506.9 & 1889.0 & 4419.0 & 859.8 & 63.2 & 265.0 & F \\
\hline $\mathbf{A 3}$ & Doğumevi & A & Sabah & 7:45-8:45 & 2286 & 14.8 & 107.9 & 2221.0 & 2392.9 & 465.6 & 34.2 & 33.9 & $\mathrm{C}$ \\
\hline A4 & Vilayet & A & Akşam & $17: 00-18: 00$ & 3401 & 153.4 & 388.5 & 2980.0 & 5863.2 & 1140.8 & 83.9 & 117.2 & F \\
\hline A5 & Gar & A & Sabah & 8:00-9:00 & 4604 & 202.8 & 511.0 & 3843.0 & 7191.4 & 1399.2 & 102.9 & 105.7 & $\mathrm{~F}$ \\
\hline A6 & Altı Eylül & A & Sabah & 8:30-9:30 & 3759 & 39.8 & 341.1 & 3671.0 & 4389.6 & 854.1 & 62.8 & 49.8 & D \\
\hline A7 & Otel Basri & A & Akşam & 18:00-19:00 & 3640 & 34.4 & 295.5 & 3609.0 & 5130.3 & 998.2 & 73.4 & 58.0 & E \\
\hline A8 & Emniyet & A & Akşam & $17: 45-18: 45$ & 3428 & 137.3 & 422.1 & 2817.0 & 7232.3 & 1407.2 & 103.5 & 182.3 & F \\
\hline A9 & $\mathrm{ADH}$ & A & Sabah & 7:30-8:30 & 2278 & 174.7 & 506.9 & 1889.0 & 4419.0 & 859.8 & 63.2 & 265.0 & $\mathrm{~F}$ \\
\hline B1 & Çardaklı & B & Sabah & 7:30-8:30 & 2341 & 35.9 & 213.5 & 2230.0 & 3651.6 & 710.5 & 52.2 & 63.9 & E \\
\hline B2 & A. Hikmet Paşa & B & Öğle & 13:00-14:00 & 1929 & 70.4 & 258.3 & 2153.9 & 3452.4 & 671.7 & 49.4 & 114.0 & $\mathrm{~F}$ \\
\hline B3 & Deve Loncası & B & Sabah & $8: 15-9: 15$ & 2383 & 23.3 & 165.1 & 2308.0 & 3144.2 & 611.8 & 45.0 & 49.1 & D \\
\hline B4 & Eski Camii & B & Akşam & 18:00-19:00 & 2023 & 18.6 & 159.6 & 2021.0 & 1963.2 & 382.0 & 28.1 & 32.9 & C \\
\hline B5 & M.Akif Ersoy & B & Sabah & 7:30-8:30 & 1336 & 14.3 & 108.8 & 1291.0 & 1694.9 & 329.8 & 24.2 & 41.0 & D \\
\hline B6 & Çengel Cad. & B & Sabah & 7:30-8:30 & 1538 & 23.3 & 143.5 & 1495.0 & 2102.4 & 409.1 & 30.1 & 50.8 & D \\
\hline C1 & Stadyum & C & Akşam & $17: 15-18: 15$ & 3171 & 82.8 & 456.8 & 2870.0 & 6568.3 & 1278.0 & 94.0 & 137.0 & $\mathrm{~F}$ \\
\hline C2 & Kapalı Spor Sal. & $\mathrm{C}$ & Akşam & $17: 15-18: 15$ & 1970 & 62.5 & 442.3 & 1843.0 & 2022.0 & 393.4 & 28.9 & 84.3 & $\mathrm{~F}$ \\
\hline $\mathrm{C} 3$ & Vergi Dairesi & $\mathrm{C}$ & Akşam & $17: 45-18: 45$ & 1242 & 0.5 & 43.9 & 1197.0 & 566.6 & 110.2 & 8.1 & 6.0 & A \\
\hline $\mathrm{C} 4$ & Ofis & $\mathrm{C}$ & Sabah & 7:30-8:30 & 874 & 0.7 & 41.6 & 820.0 & 463.5 & 90.2 & 6.6 & 14.1 & B \\
\hline C5 & Ağır Bakım & C & Sabah & 7:30-8:30 & 1798 & 14.8 & 350.0 & 1756.0 & 1666.3 & 324.2 & 23.8 & 28.9 & D \\
\hline C6 & Atay Cad & $\mathrm{C}$ & Sabah & 7:30-8:30 & 1386 & 1.2 & 128.1 & 1347.0 & 1012.2 & 196.9 & 14.5 & 11.2 & B \\
\hline C7 & Altıntaşlar & $\mathrm{C}$ & Sabah & 7:30-8:30 & 1456 & 0.7 & 67.3 & 1406.0 & 796.1 & 154.9 & 11.4 & 6.7 & A \\
\hline $\mathrm{CB}$ & RüzgarCad & $\mathrm{C}$ & Akşam & $16: 00-17: 00$ & 1420 & 13.4 & 196.3 & 1385.0 & 1032.2 & 200.8 & 14.8 & 20.7 & C \\
\hline C9 & Savaştepe & $\mathrm{C}$ & Akşam & 17:00-18:00 & 1229 & 0.3 & 28.3 & 1172.0 & 735.8 & 143.2 & 10.5 & 5.3 & A \\
\hline
\end{tabular}


Çalışmada elde edilen sonuçlara göre ve Tablo 3'de sunulan istatistikler yardımıyla, en yüksek taşıt geçişi, ana arter üzerinde yer alan A5 kodlu Gar Kavşağında gerçekleștirilmiş olup, sabah saat 8:00 ile 9:00 arasında yaklaşık 4604 taşı geçiş yapmıştır. Gar kavşağının yoğunluk düzeyi "F" olarak tespit edilmiştir. Tüm kavşaklara ait taşıt geçiş değişimleri Şekil 6' da verilmiştir. Benzer ifadeyle, en düşük taşıt geçişi, ana arterin Doğu bölümünde yer alan C4 kodlu Ofis Kavşağında gerçekleştirilmiş olup, sabah saat 7:30 ile 8:30 arasında yaklaşık 874 taşı geçiş yapmıştır. Ofis kavşağının yoğunluk düzeyi ise "B" olarak tespit edilmiştir. Tüm kavşaklara ait taşıt geçişlerine ait değişimler Şekil 6' da sunulmuştur.

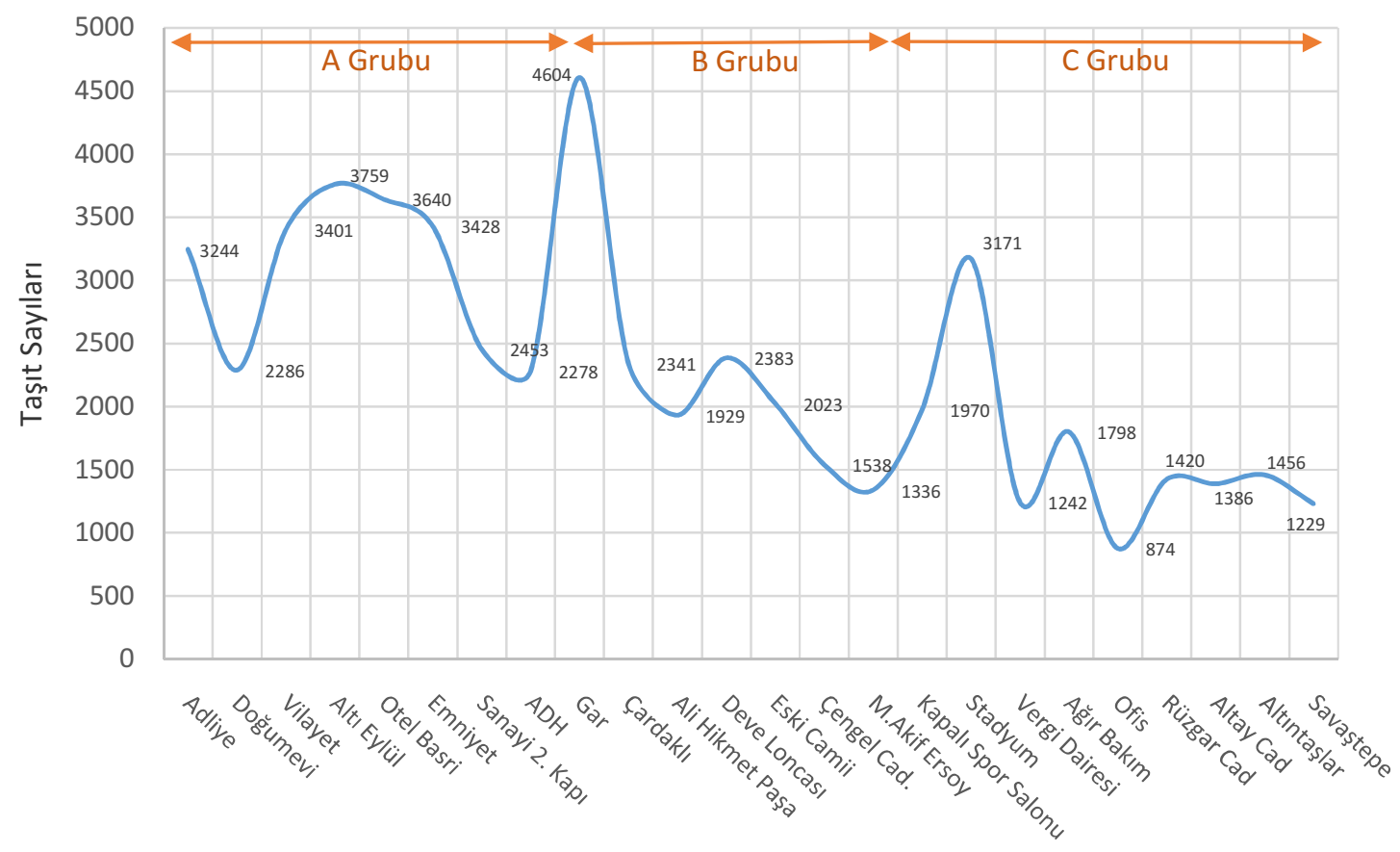

Şekil 6. Kavşaklara ait taşınım değişimleri.

Araç sayımı yapılan tüm kavşaklar genel olarak incelendiğinde, Şekil 6'da sunulan taşınım değişimleri dikkate alındığında, İzmir-Bursa-İstanbul hattı üzerinde olan ve şehir merkezinden geçen ana arter üzerindeki kavşakların (A grubu) daha yoğun araç trafiğine sahip oldukları anlaşılmaktadır. Ana arterin, bir başka ifadeyle A Grubu kavşakların Batısında bulunan B Grubu kavşaklarda, A grubu kavşaklara nispeten daha az araç geçişi gözlenmiştir. B Grubu kavşaklara daha çok eski şehir merkezinde ve alışveriş merkezlerinin daha çok yoğun olduğu bölgelerde bulunduğundan ana arter bağlantılarına göre daha az taşıt yoğunluğu oluşmaktadır. Yerleşim alanlarının ve daha çok sanayi-imalat tesislerinin olduğu yerleri temsil eden C Grubu kavşaklarda ise en az taşıt geçişlerinin meydana geldiği tespit edilmiştir. C Grubunda oluşan istisnai durum ise, Stadyum kavşağının (C1) lokasyonu ve taşıt yoğunluğudur. Stadyum kavşağı, şehir merkezinde yerleşim alanlarında yaşayan daha fazla nüfusun gerek iş hayatları gerekse güncel sosyal faaliyetleri için günün her saati sürekli olarak kullandıkları bir geçiş noktası olma özelliğindedir. Bu nedenle, ikinci en yüksek taşıt geçişi bu kavşakta tespit edilmiştir.

Kavşaklara ait gruplar arası taşıt geçişlerinin istatiksel olarak kıyaslanması için ANOVA (ANalysis Of VAriance) testi yapılmıştır [15]. Test sonucuna göre, her bir Gruba ait kavşaklardan geçen ortalama araç sayıları \%95 önem düzeyine göre kıyaslanmış ve kavşaklara ait ortalamaların istatiksel olarak anlamlı ve dolayısıyla 
birbirinden farklı olduğu sonucuna varılmıştır $(\mathrm{p}=0,00)$. Gruplara ait farklı ortalama araç geçişlerini yine \%95 önem düzeyinde analiz etmek için yapılan Post-Hoc (LSD) testi sonuçlarına göre, A Grubu kavşaklardan geçen ortalama $\left(\mu_{\mathrm{AGrubu}}\right)$ araç sayısının $\left(\mu_{\mathrm{AGrubu}}=3232\right.$ araç $)$ matematiksel olarak en yüksek değerde olduğu istatiksel olarak da diğer gruplardan farklı olmasının anlamlı olduğu $(\mathrm{p}=0.001)$ belirlenmiştir. Aynı test sonucuna göre, bir diğer önemli bulgu ise, B Grubu ve C Grubu kavşaklarından geçen ortalama araç sayıları arasındaki farkın istatiksel olarak anlamlı olmadığı $(\mathrm{p}=0.387)$

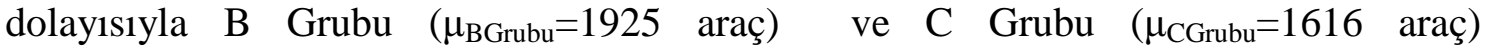
kavşaklarından geçen ortalama araç sayılarının istatiksel olarak bir fark teşkil etmediği sonucuna ulaşılmıştır. Dolayısıyla, ana arterin Batı ve Doğu kısımlarında bulunan kavşaklarda taşıt geçiş yoğunluğu açısından fark yoktur.

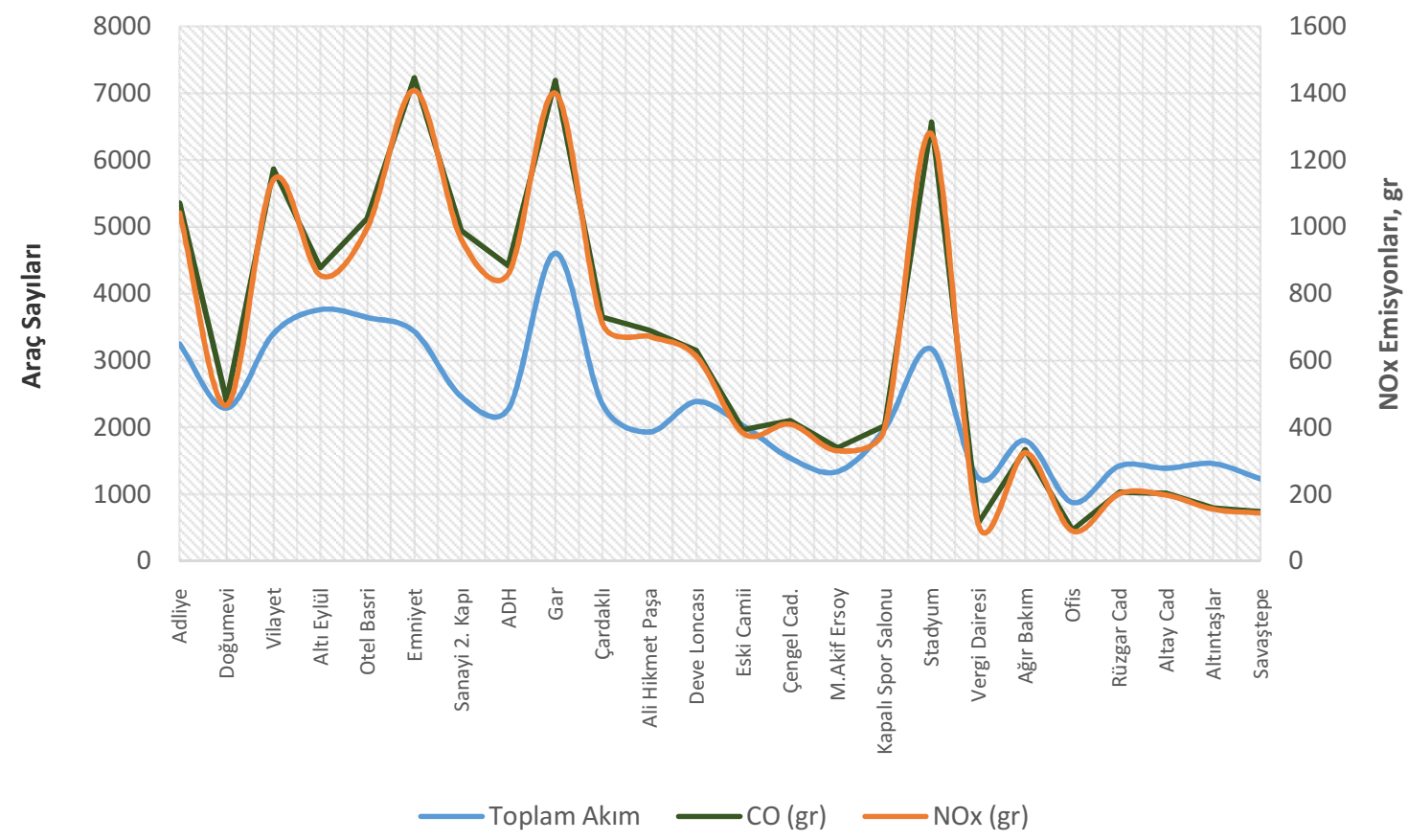

Şekil 7. Kavşaklara ait araç geçişleri ve kirletici emisyonları değişimi.

İncelenen kavşaklardaki araç geçiş sayıları belirlendikten sonra, COPERT programı çalışma alanı için bir simülasyon modeli oluşturulmuştur. Her bir kavşak için, araç geçiş sayıları ve araçların tipleri göre $\mathrm{CO}, \mathrm{NO}_{\mathrm{x}}$ kirleticilerine ait emisyon değerleri ve ayrıca kavşaklardan geçen her bir araç sınıfı için yakıt tüketim indekslerine göre yakıt tüketim değerleri tahmin edilmiştir. Simülasyon modeline ait sonuçlar Tablo 3'de her bir kavşak için sunulmuştur.

Hava kirletici emisyonlarına ait değişimler incelendiğinde, Şekil 7'de gösterildiği üzere, en yükssek $\mathrm{CO}$ ve $\mathrm{NO}_{\mathrm{x}}$ salınımları, taşıt geçişlerinin en yoğun olduğu A4, A5 ve C1 kodlu kavşaklarda olduğu tahmin edilmiştir.

Kavşak grupları arasında $\mathrm{CO}$ ve $\mathrm{NO}_{\mathrm{x}}$ emisyonları ortalamalarının farklılığı incelendiğinde, yine yapılan ANOVA testleri sonucunda kavşak grupları arasındaki CO ve $\mathrm{NO}_{\mathrm{x}}$ emsiyon seviyelerinin farklı olduğu ( $\mathrm{CO}$ için $\mathrm{p}=0.00$ ve $\mathrm{NO}_{\mathrm{x}}$ için $\mathrm{p}=0.00$ ) belirlenmiştir. Bu farklar arasında yapılan Post-Hoc (LSD) ikili kıyaslama testlerine göre ise en yüksek $\mathrm{CO}$ emisyon kaynağının, A Grubu kavşaklar $\left(\mu_{\mathrm{AGrubu}}=5212 \mathrm{gr} \mathrm{CO}\right)$ olduğu ( $\mathrm{p}=0.005$ ) ve $\mathrm{B}$ Grubu ve $\mathrm{C}$ Grubu kavşaklarda oluşan $\mathrm{CO}$ emisyon seviyeleri farkının istatiksel olarak anlamlı olmadığ $(p=0.228)$ dolayısıyla B Grubu 
$\left(\mu_{\mathrm{BGrubu}}=2668.12\right.$ gr CO$)$ ve C Grubu $\left(\mu_{\mathrm{CGrubu}}=1651.44\right.$ gr CO$)$ kavşaklarından diş ortama salınan ortalama $\mathrm{CO}$ emisyonlarında istatiksel olarak bir fark teşkil etmediği sonucuna ulaşılmıştır.

Benzer sonuç, söz konusu 3 gruba ait kavşaklardan geçen araçlardan diş ortama salınan $\mathrm{NO}_{\mathrm{x}}$ emisyonu için de geçerli olup, en yüksek $\mathrm{NO}_{\mathrm{x}}$ emsiyonu yine $\mathrm{A}$ Grubu kavşaklarda $\left(\mu_{\mathrm{AGrubu}}=1014.18 \mathrm{gr} \mathrm{NO}_{\mathrm{x}}\right)$ oluştuğu belirlenmiştir. Yine, $\mathrm{B}$ Grubu ve $\mathrm{C}$ Grubu kavşaklarda oluşan $\mathrm{NO}_{\mathrm{x}}$ emisyon seviyeleri farkının istatiksel olarak anlamlı olmadığı $(\mathrm{p}=0.228)$ dolayisiyla B Grubu $\left.\left(\mu_{\mathrm{BGrubu}}=519.5 \mathrm{gr} \mathrm{NO}\right)_{\mathrm{x}}\right)$ ve $\mathrm{C}$ Grubu $\left(\mu_{\mathrm{CGrubu}}=321.3 \mathrm{gr}\right.$ $\mathrm{NO}_{\mathrm{x}}$ ) kavşaklarından dış ortama salınan ortalama $\mathrm{NO}_{\mathrm{x}}$ emisyonlarında istatiksel olarak bir farkın oluşmadığ 1 anlaşılmıştır.

Her bir kavşak grubundan geçen araç sayılarına ait ortalama yakıt tüketimlerine ait istatiksel analiz sonuçları da daha önce ifade edilen $\mathrm{CO}$ ve $\mathrm{NO}_{\mathrm{x}}$ emisyon seviyeleri için elde edilen sonuçlara benzer nitelikte olup, yine en yüksek yakıt tüketimi hem kavşak yoğunluk düzeyleri hem de kavşakta söz konusu yoğunluktan dolayı artan bekleme süreleri de dikkate alındığında A Grubu kavşaklarda yine en yüksek ortalama yakıt tüketiminin ( $\mu_{\mathrm{AGrubu}}=74.58$ gr) olduğu belirlenmiştir. Diğer iki kavşak gruplarında benzer ve tipik sonuçlar elde edilmiş olup B Grubu ( $\left.\mu_{\mathrm{BGrubu}}=38.17 \mathrm{gr}\right)$ ve $\mathrm{C}$ Grubu $\left(\mu_{\text {CGrubu }}=23.62\right.$ gr $)$ kavşaklarında ortalama yakıt tüketimi farkının istatiksel olarak anlamlı olmadığı $(\mathrm{p}=0.228)$ ve dolayısıyla, ana arterin Batı ve Doğu kısımlarında bulunan kavşaklarda geçen veya bekleyen araçların ortalama yakıt tüketimleri açısından fark olmadığ 1 tespit edilmiştir.

İnceleme yapılan kavşaklarda oluşan tahmini araç dizisi (araç kuyruğu) değerleri (QLen) ile aynı kavşaklarda oluşan yakıt tüketimleri arasında yapılan Korelasyon analizi ile Pearson Korelasyon katsayısı hesaplanmış olup, bu sonucuna göre, kavşakta sinyalizasyon ve araç yoğunluğu nedeni ile oluşan araç kuyruğu uzunlukları ile o kavşaktaki araçların yakıt tüketimleri arasında yaklaşık \%79.4 $(\mathrm{p}=0.00)$ oranında pozitif yönde bir korelasyon olduğu tespit edilmiştir. Araç dizilerindeki artış, söz konusu araçların yakıt tüketimlerinin de artmasına neden olduğu ifade edilebilir.

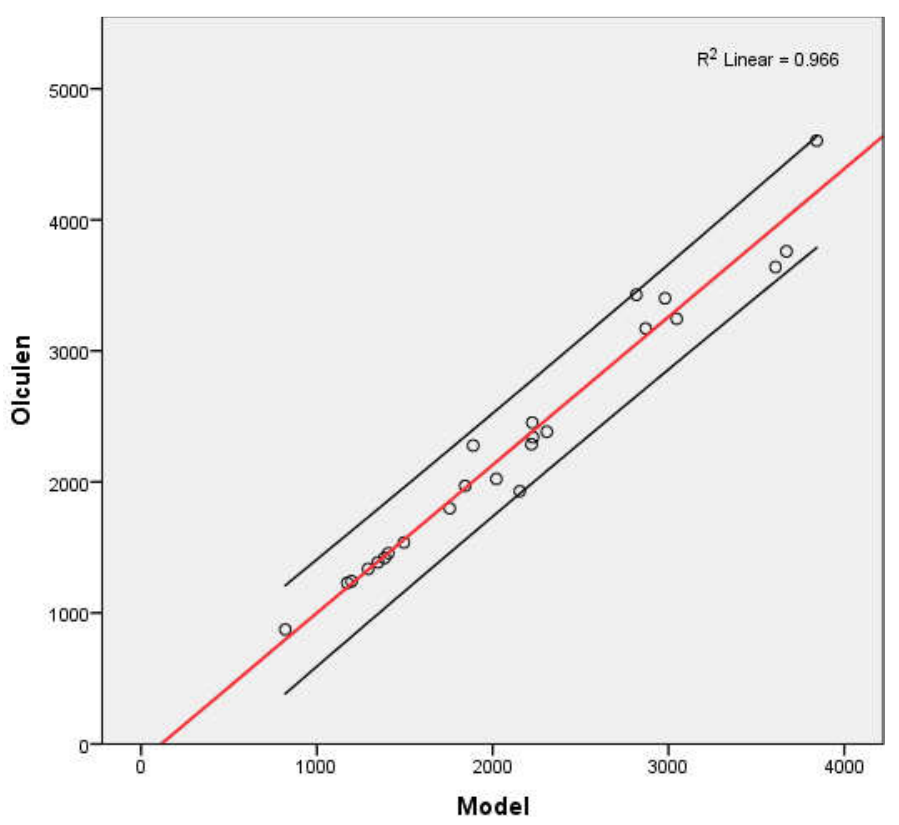

Şekil 8. Gerçek araç sayıları ile tahmini araç sayıları arasındaki ilişki. 
Emisyon ve yakıt tüketimi hesaplarında kullanılan COPERT modelinin geçerliliği önemli bir durum arz etmektedir. $\mathrm{Bu}$ nedenle kullanılan modelden elde edilen sonuçların tutarlılığını incelemek için, her bir kavşakta ölçülen araç sayımları ile COPERT simülasyon modelinde tahmin edilen modellenmiş araç sayıları (VEHS) arasında yapılan kıyaslama sonucunda, Şekil 8'de sunulduğu gibi, \%96.6 doğruluk düzeyinde (\%95 önem düzeyinde alt ve üst limit güven aralıkları (CI) ile birlikte) tahmin edilen araç sayılarının tutarlı olduğu ifade edilebilir. Hava kirletici salınımları, araçlara ait yakıt tüketim değerleri doğrudan kavşaklardan geçen araç sayıları ile ilişkili olduğundan, COPERT programında tahmin edilen araç sayılarının yüksek oranda gerçek sayım değerleri ile kıyaslanması COPERT programının kirletici emisyonları ve yakıt tüketimleri için yapmış olduğu tahminlerinde tutarlı olduğu sonucuna varılmaktadır.

Çalışma sonucunda, Balıkesir ilinde incelenen toplam 24 kavşakta oluşan trafik faaliyetleri sonucunda sıcak ve soğuk iklim özellikleri dikkate alınarak yapılan analizler sonucunda yıllık olarak yaklaşık 682 ton $\mathrm{CO}$ ve 133 ton $\mathrm{NO}_{\mathrm{x}}$ emisyonlarının trafik kaynaklı olarak atmosfere salındığı tahmin edilmektedir. Kocaeli'nde yapılan trafik kaynaklı hava kirliliği seviyelerinin araştırıldığı benzer bir çalışmada, tahmin edilen yıllık CO emisyonları 3769 ton ve NOx emisyonlarının ise 4029 ton olarak rapor edilmiştir [16]. Bartın ili için oluşturulan "Hava Kalitesi Analiz Raporu 2009-2014" konulu çalışmada ise Bartın ilinde trafik kaynaklı kirletici miktarları yıllık şehir içi CO miktarı 982 ton ve NOx miktarı ise 673 ton olarak belirtilmiştir [17]. Gaziantep' de yapılan bir başka çalışmada [17] ise, il merkezinde tüm yakıt türevlerinden oluşan yıllık NOx miktarı yaklaşık 453 ton olarak tahmin edilmiştir. Goyal ve ark. [19], tarafından yapılan benzer bir çalışmada, Hindistan' da Delhi bölgesinde hızlı gelişen yerlerde yıllık ortalama CO emisyonlarının 509 ton ve $\mathrm{NO}_{\mathrm{x}}$ emisyonlarının ise 194 ton olarak tahmin edildiği belirtilmiştir. Trafik akışlarında sık yapılan dur/kalk, ani fren, bekleme veya farklı hızlarda araçların seyir halinde olması şehir merkezilerindeki trafik kaynaklı kirletici salınımlarını arttırmaktadır. Akay ve Akgüngör [20], yapmış oldukları çalışmada yeşil dalga uygulamasının her ne kadar cadde içi emisyonları \%3 oranında arttırmasına rağmen, özellikle kavşaklardaki beklemeden kaynaklı salınımlarda yaklaşık \%81 ve kalkışlarda \%77 oranında azalma olduğunu tespit etmişlerdir. Yine aynı çalışmada, yeşil dalga uygulamasının kavşaklardaki yoğunluğu azaltıcı etkisinin yanında CO emisyonu salınımlarında yaklaşık \%77 oranında bir azalma olabileceğini ifade etmişlerdir.

\section{Tartışma}

Balıkesir il merkezinde yapılan bu çalışma ile karayolu trafiğinden kaynaklanan hava kirliliği seviyelerinin araştırılması ve hava kirleticilerinin emisyon envanterlerinin belirlenmesi amaç edilmiştir. Çalışmada, toplam 24 kavşakta araç sayımları yapılmış ve sayım değerleri COPERT simülasyon modelinde işlenerek analiz edilmiştir.

Çalışma sonucunda, il merkezi içerisinden de geçen İzmir-Bursa-İstanbul ana ulaşım hattı üzerinde bulunan kavşaklarda trafik yoğunluğunun daha fazla ve dolayısıyla atmosfere verilen $\mathrm{CO}$ ve $\mathrm{NO}_{\mathrm{x}}$ kirleticileri ile yakıt tüketimlerinin daha fazla olduğu tespit edilmiştir. Ana hattın Batı ve Doğu kısımlarını temsil eden kavşak gruplarındaki trafik yoğunluğu nispeten çok daha az olduğu belirlenmiştir. Genel olarak, Balıkesir il merkezinde trafik faaliyetlerinden kaynaklı oluşan $\mathrm{CO}$ ve $\mathrm{NO}_{\mathrm{x}}$ emsiyonları diğer büyük 
şehirlerdeki seviyeler ile kıyaslandığında nispeten düşük olduğu göze çarpmaktadır. Bu durum il merkezine ait nüfus yoğunluğunun çok fazla olmaması, yaşam yerleri tercihlerinin ana ulaşım hattının doğu ve batısındaki bölgelerde olması ve sanayi faaliyetlerinin diğer şehirlere göre nispeten sınırlı olması olarak açıklanabilir.

Ill merkezinde ileride trafikten kaynaklı hava kirliliği konusunda ciddi anlamda sorun yaşanmaması için şehir içi trafik akışını asgari seviyede kesintisiz olarak sürdürülebilmesi, bekleme, dur/kalk miktarlarının azaltılması, her zaman olduğu gibi toplu taşıma araçlarının kullanımlarının özendirilmesi, kamuya ait araçlarda yeşil enerji kapsamında alternatif olabilecek çevre dostu yakıtların kullanılması önem arz etmektedir. Özellikle ana hatlar üzerinde mutlaka yeşil dalga sisteminin ve (A5) Gar, (A1) Adliye, (A8) Emniyet gibi kavşaklarda imkanlar dahilinde köprülü kavşak veya battı/çıktı kavşakların yapılması öngörülmektedir. Halen il merkezinde, çalışmada kullanılan verilerin temin edildiği zamandan bu yana, A7 Otel Basri kavşağında köprülü kavşak ve A8 Emniyet kavşağında ise battı/çıktı kavşağı yapım aşamaları tamamlanmış ve hizmete girmiş olup, halen A1 Adliye kaşağındaki köprülü kavşak inşaatı yapım aşamasında devam etmektedir. İleride yapılması öngörülen çalışmalarda, araçlara ait farklı yakıt tipleri dikkate alınarak oluşturulacak bir kirletici emisyon envanteri ve bu envanterin mevsimsel dağılımlarının incelenmesi önem arz etmektedir.

\section{Teşekkür}

Bu çalışmanın gerçekleşmesinde Balıkesir İli Valiliği kapsamında Çevre ve Şehircilik İl Müdürlüğü yetkililerine teşekkürlerimi arz ederim.

\section{Kaynaklar}

[1] Lejri, D., Can, A., Schipre, N., ve Leclercq, L., Accounting for traffic speed Dynamics when calculating COPERT and PHEM pollutant emissions at the urban scale. Transportation Reasearch Part D, 63,588-603, (2018). https://doi.org/10.1016/j.trd.2018.06.023

[2] WHO, Health effects of transport-related air pollution. Copenhagen, WHO Regional Office for Europe. Denmark, (2005).

[3] Khan, J.,Ketzel, M., Kakosimos, K., Sorensen, M. ve Jensen,S.S., Road traffic air and noise pollution exposure assessment - A review of tools and techniques. . Science of The Total Environment, 634, 661-676, (2018). https://doi.org/10.1016/j.scitotenv.2018.03.374

[4] Forehead, H. ve Huynh, N.,Review of modelling air pollution from traffic at street-level - The state of the science, Environmental Pollution, 241, 775-786, (2018). https://doi.org/10.1016/j.envpol.2018.06.019

[5] Pan, L.,Yao, E., ve Yang,Y., Impact analysis of traffic-related air pollution based on real-time traffic and basic meteorological information, Journal of Environmental Management, 183, 3, 510-520, (2016). http://dx.doi.org/10.1016/j.jenvman.2016.09.010

[6] EEA, Air quality in Europe-2015 Report. The European Environment Agency, http://www.eea.europa.eu/publications/air-quality-in-europe-2015. (18.06.2018) 
[7] Elbir, T., Bayram, A., Kara, M., Altıok, H., Seyfioğlu, R., Ergün, P., Şimşir, S., İzmir kent merkezinde karayolu trafiğinden kaynaklanan hava kirliliğinin incelenmesi, Dokuz Eylül Üniversitesi Mühendislik Fakültesi Mühendislik Bilimleri Dergisi, 12,1, 1-17, (2010).

[8] Bagieński, Z., Traffic air quality index, Science of The Total Environment, 505, 606-614, (2015). http://dx.doi.org/10.1016/j.scitotenv.2014.10.041

[9] Zhang, K. ve Batterman, S.,Air pollution and health risk due to vehicle traffic. Science of The Total Environment, 15, 307-316, (2013). https://doi.org/10.1016/j.scitotenv.2013.01.074

[10] EEA, Traffic pollution still harmful to health in many parts of Europe, European Environment Agency Report. Copenhagen, Denmark, (2012).

[11] TRAP, Traffic related air pollution, Air Quality Ontario, Canada. http://www.simcoemuskokahealthstats.org/topics/environment/outdoor-airquality/traffic-related-air-pollution, (12.7.2018)

[12] HEI, Traffic related air pollution: a critical review of the literature on emissions, exposure, and health effects. Clean Air Act Advisory Commitee, HealtEffectInstitue, Virginia, USA, (2009).

[13] COPERT, Computer programme to calculate emissions from road transportCOPERT 4. User Manual. European Environment Agency, (2012).

[14] TÜİK, Türkiye İstatistik Kurumu, Motorlu kara taşıtları 2016 yılı verileri, (2016). http://www.tuik.gov.tr/PreHaberBultenleri.do?id=24595 (12.08.2018).

[15] IBM SPSS, IBM SPSS StatisticsVersion 20, IBM Corporation, N.Y., USA. (2015)

[16] Çetin, Ş., Karademir, A., Pekey, B. ve Ayberk, B., Kocaeli ili'nde trafik kaynaklı hava kirleticilerinin emisyon envanteri, Kocaeli Özelinde Büyükşehirlerin Kentsel Yapılaşma ve Ulaşım Sorunları Sempozyumu, Kocaeli Üniversitesi, Kocaeli, (2006).

[17] ÇSB, Bartın ili hava kalitesi analiz raporu (2009-2014), Çevre ve Şehircilik Bakanlığı. Ankara, (2015).

[18] Cuci, Y. ve Polat, E.E., Gaziantep'in trafik kaynaklı hava kirliliğinin belirlenmesi. KSU Mühendislik Bilimleri Dergisi, 18, 2, 1-11, (2015).

[19] Goyal P.,Mishra D. ve Kumar A. Vehicular emission inventory of criteriapollutants in Delhi. Springerplus, 2,216, 1-11, (2013). https://doi.org/10.1186/2193-1801-2-216

[20] Akay, M.E. ve Akgüngör, A.P., Taşıt emisyonlarının azaltılmasında trafik 1şıklarının senkronizasyon etkisinin modellenmesi. Politeknik Dergisi, 11,1, 5156, (2008). https://doi.org/10.2339/2008.11.1.51-56 